\title{
Vreugde en verdriet in die \\ huis van Jakob
}

\author{
Paul Krueger \\ Skool vir Bybelwetenskappe en Antieke Tale \\ Noordwes-Universiteit (Potchefstroomkampus)
}

\begin{abstract}
Happiness and lament in the house of Jacob

The birth narrative in Genesis 29:31-30:24 is a coherent mini drama in its own right, although it is embedded in the patriarchal narratives and as such furnishes important background to the unfolding drama in Jacob's house. In this narrative, the reader is invited right into the intricate family relations of a dysfunctional polygamous marriage, where two rivals communicate with each other and their mutual husband by means of the names given at birth to their children and the children of their slave girls. This article focuses on the quest for happiness, which is evident in the births and name-giving in the house of Jacob. Although true happiness remains elusive, at the end both women receive their dues. God keeps a balance between the two contenders, but the birth of Rachel's son calls for a resolution still to come. The text is thus left open ended.
\end{abstract}

\section{INLEIDING}

Die geboortevertelling ${ }^{1}$ in Genesis 29:31-30:24 is uniek in die Hebreeuse Bybel omdat dit fokus op ingewikkelde verhoudings in 'n poligame huwelik. Die leser word ingelei in die "mikrokosmos" (Fokkelmann 1975:131), die intiem-persoonlike wêreld van Jakob se huis. Hierdie artikel fokus op die geboortevertelling as 'n mini-drama met sy eie spanningslyn. Die makrowêreld van die vertelling, naamlik historiese vrae rakende die plek en funksie van die vertelling binne sy onmiddellike tekstuele konteks en in die boek Genesis, asook die bedoeling van die vertelling binne die sosiohistoriese opset van die eerste lesers en veral binne die patriargale samelewing, is buite die fokus van die artikel.

\footnotetext{
${ }^{1}$ Hierdie teks staan onder verskillende name bekend, byvoorbeeld: Geboortevertelling van Jakob se seuns (Erzählung von der Geburt der Jakobsöhne) (Lehming 1963), Wedywering om geboorte te skenk (Gebärwettstreit) (Wahl 1997; Meurer 2001), Storie van Ragel en Lea (Bellis 1999) of Geboorte en naamgewing van Jakob se seuns (Westermann 1981).
} 


\section{Vreugde en verdriet in die huis van Jakob}

In hierdie artikel word veral gekyk hoe vreugde en verdriet in die naamgewing van die seuns van Jakob tot uitdrukking kom. Vreugde behels in die bespreking sinonieme soos blydskap, genot, vervulling, en tevredenheid. Verdriet, wat in dieselfde breë semantiese domein as vreugde is, behels leed, smart, ontsteltenis, swaarmoedigheid, mistroostigheid en ontevredenheid. ${ }^{2}$ Die twee begrippe hou verband met 'n gevoel van onderskeidelik oorwinning en mislukking. Die klem val in die artikel nie net op spesifieke Hebreeuse woorde wat vreugde en verdriet uitdruk nie, maar veral op die saak, wat soms indirek uit die naamgewing van die kinders blyk.

\section{EENHEID VAN DIE TEKS}

Kratz (2000:271) oordeel dat die teks oor die algemeen (von jederman) ervaar word as iets wat nie 'n eenheid vertoon nie. Daardeur vertolk hy die siening van verskeie Ou-Testamentici van 'n geslag tevore, wat die teks as 'n ingewikkelde sameflansing van uiteenlopende bronne beskou (bv Speiser 1964:232-233; Von Rad 1972:236-237; Seebass 1999:343-345). Volgens hierdie siening het 'n redaktor hierdie saamgestelde teks by die vertelling oor die geskil tussen Jakob en Laban ingevoeg. Westermann (1981:574-576, 582) beskou die teks nie as gewone vertelteks nie, maar eerder as 'n tipe geslagsregister wat 'n ouer Jahwistiese vertelteks oorskryf.

Verskeie kontemporêre eksegete beklemtoon egter dat die teks 'n gestruktureerde vertelling is (bv Wahl 1997:223; Taschner 2000:91-92). Seebass (1999:338) wys daarop dat spanning in die teks ontvou veral in die naamgewing en meer spesifiek in die begronding van die name. Meurer (2001:93-108) dui oortuigend die literêre eenheid van hierdie teks aan en noem dit 'n afgeslote, afgeronde en selfstandige vertelling met 'n duidelike vertellyn (plot). Fokkelmann (1975:133) sê dat die name van die kinders en die betekenisse wat daaraan geheg word, wesentlik is vir die ontplooiing van die geboortevertelling en dat dit terselfdertyd die tema (main point) van die van die verhaal is. Callaway (1986:26) praat van 'n gespanne drama, waarin dit nie soseer oor die oorsprong van die stamme van Israel gaan nie, maar veel eerder oor die verhouding tussen Lea en Ragel.

Die teks word sowel aan die begin (29:1) as aan die einde (30:24) duidelik afgegrens van die omliggende teks, wat oor Jakob se verhouding met Laban handel:

\footnotetext{
${ }^{2}$ Vreugde behels ongeveer die semantiese domein 25.116-134 en verdriet die semantiese domein 25.228-296 wat Louw \& Nida (1989:302-304, 319-320) onderskei. Genoemde semantiese domeine word deur Swanson (1998) op Bybelse Hebreeus toegepas. Dit kom ook ongeveer ooreen met die semantiese domeine 718 tot 721 wat De Stadler (1994) ten opsigte van Afrikaans onderskei.
} 
- Die teks begin met 'n geboorte, naamlik die eersteling van Lea (29:30$31)$ en eindig met ' $n$ geboorte, naamlik die eersteling van Ragel (30:2224).

- Aan die begin van die teks (29:31) word die tema aangegee, naamlik dat Jakob nie vir Lea liefhet nie, maar dat die Here vir haar kinders gee, terwyl Ragel kinderloos bly. Die teks eindig met 'n gedeeltelike ontknoping, waar Ragel geboorte gee aan haar eersteling (30:22-24). Daardeur word die teks tematies omraam.

Die teks begin en eindig met die uitdruklike vermelding van die Naam יהוה, terwyl die Naam אֶלהים in die middelste deel van die teks gebruik word. Uitgaande van die Bronnekritiek sien sommige verklaarders die wisseling in die Godsnaam as aanduiding van 'n onderliggende J- en E-bron (Seebass 1999:345). Die gebruik van die Naam יהוה aan die begin en einde van perikope is egter ' $n$ tipiese wyse waarop perikope in Genesis van mekaar onderskei word (Wenham 1994:249) en kan dus as 'n aanduiding van eenheid in die teks se Endgestalt beskou word.

In hierdie artikel word die geboortevertelling as 'n sterk gestruktureerde teks benader. Gesinsverhoudings in die huis van Jakob ontwikkel (of eerder: versleg), sodat daar elemente van 'n klimaktiese vertelteks herkenbaar is.

\section{INDELING: DRIE MAAL VIER}

Meurer (2001:101-103) verdeel die geboortevertelling in vier segmente wat ' $n$ konsentriese patroon vertoon:

a Die geboorte van Lea se seuns (29:31-35)

b Die geboorte van Ragel se seuns uit haar slavin, Bilha (30:1-8)

b' Die geboorte van Lea se seuns uit haar slavin, Silpa (30:9-16)

$\left.\begin{array}{l}\text { Die geboorte van Lea se seuns en dogter } \\ \text { en die geboorte van Ragel se seun }\end{array}\right\}(30: 17-24)$

Die motivering vir hierdie indeling is hoofsaaklik die gebruik van trefwoorde.

Die buitesegmente begin beide deur op Jahwe/God se waarneming te wys:

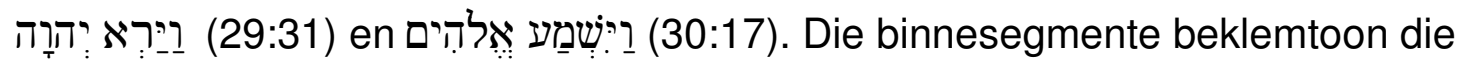

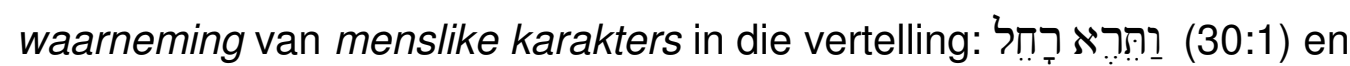
(30:9). 
Segmente b en b' kan ook as ' $n$ enkele segment beskou word, aangesien beide oor die kinders van die slavinne handel en daar 'n konsentriese patroon tussen dié twee segmente aangedui kan word:

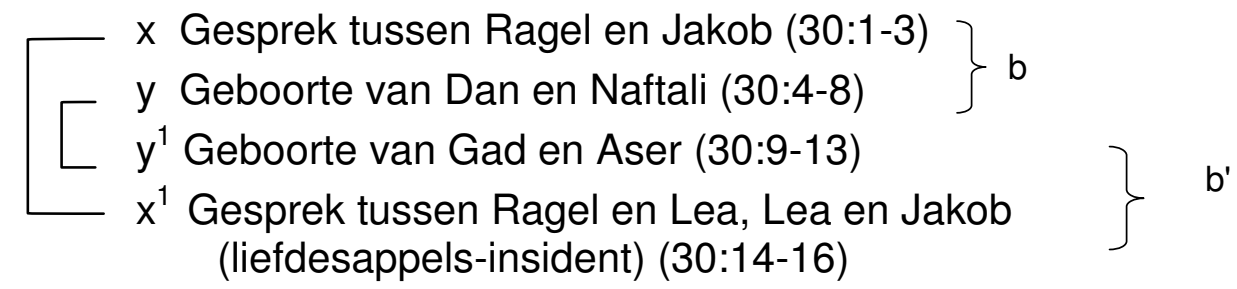

Die aard van die gesprekke in $x$ en $x^{1}$ verskil egter sodanig, dat hier nie werklik van 'n inclusio sprake is nie. Verskeie eksegete, byvoorbeeld Fokkelmann (1975:132), Sarna (1989:206-209), Seebass (1999:227) en Waltke (2001:408), volg daarom 'n driedeling (a-b-a'), waarin die liefdesappels-insident (30:14-16) $\left(x^{1}\right)$ by die laaste segment $\left(a^{1}\right)$ geplaas word. So 'n indeling maak inhoudelik goed sin en word in die verdere bespreking nagevolg:

$$
\begin{array}{ll}
\S 1(=a) & \text { Die Here gee slegs aan Lea kinders (29:31-35) } \\
\S 2(=b) & \begin{array}{l}
\text { Ragel en Lea wedywer om kinders } \\
\text { deur middel van Bilha en Silpa (30:1-13) }
\end{array} \\
\S 3\left(=a^{1}\right) & \text { Lea en Ragel wedywer deur liefdesappels en gebed (30:14-24) }
\end{array}
$$

Segmente 2 en 3 begin elk met 'n kort vertelling wat dialoog insluit, waarna geboortes volg. Ragel is die leidende figuur in elk van inleidende vertellings van segment 1 en 2 . Dit sluit goed aan by die ontknoping van die hele teks, waar die geboorte van Ragel se eersteling verhaal word (30:22-24). Elk van die drie segmente verhaal die geboorte van vier kinders.

Die volgende elemente word in die bespreking as paragrawe (kleiner segmente) binne die drie groot segmente van die vertelling beskou. Elemente wat tipies is aan klimaktiese verteltekste (Longacre \& Levinsohn 1978:104110; Dillard \& Longman 1994:32-34; Longacre 1996:33-38) word in die laaste kolom aangedui en in die verdere bespreking genoem. Die Afrikaanse benamings in die laaste kolom is dié van Krueger (2000:59-60, 497): 


\begin{tabular}{|c|c|c|c|}
\hline \multirow{5}{*}{$\begin{array}{l}\text { \$1 } \\
\text { Die Here gee } \\
\text { slegs aan Lea } \\
\text { kinders }\end{array}$} & Inleiding en temastelling & & \multirow{5}{*}{$\begin{array}{l}\text { Uitpak (exposition) } \\
\text { Prikkel (inciting incidents) }\end{array}$} \\
\hline & Ruben (1) & 29:32 & \\
\hline & Simeon (2) & $29: 33$ & \\
\hline & Levi (3) & $29: 34$ & \\
\hline & Juda (4) & $29: 35$ & \\
\hline \multirow{5}{*}{$\begin{array}{l}\text { \$2 } \\
\text { Ragel en Lea } \\
\text { wedywer om } \\
\text { kinders deur } \\
\text { middel van } \\
\text { Bilha en Silpa }\end{array}$} & Ragel se uitbarsting & $30: 1-3$ & \multirow{5}{*}{$\begin{array}{l}\text { Verwikkeling } \\
\text { (developing conflict) }\end{array}$} \\
\hline & $\operatorname{Dan}(5)$ & $30: 4-6$ & \\
\hline & Naftali (6) & $30: 7-8$ & \\
\hline & Gad (7) & $30: 9-11$ & \\
\hline & Aser (8) & $30: 12-13$ & \\
\hline \multirow{6}{*}{$\begin{array}{l}\text { §3 } \\
\text { Lea en Ragel } \\
\text { wedywer deur } \\
\text { liefdesappels } \\
\text { en gebed }\end{array}$} & Die liefdesappels-insident & $30: 14-16$ & Knoop (climax) \\
\hline & Issaskar (9) & $30: 17-18$ & \multirow{3}{*}{$\begin{array}{l}\text { Ontknoping 1) } \\
\text { (denouement 1) }\end{array}$} \\
\hline & Sebulon (10) & $30: 19-20$ & \\
\hline & Dina $(+1)$ & $30: 21$ & \\
\hline & Josef (11) & $30: 22-24$ & $\begin{array}{l}\text { Ontknoping 2) } \\
\text { (denouement 2) of } \\
\text { loswikkeling } \\
\text { (final suspense) }\end{array}$ \\
\hline & $\begin{array}{l}\text { Slot: Uitsig op nog 'n seun } \\
\text { Benjamin (12) }\end{array}$ & $30: 24 b$ & Sloteenheid (closure) \\
\hline
\end{tabular}

\section{DIE AANLOOP}

In die voorafgaande perikoop word die nodige agtergrond vir die geboortegeskiedenis met sy vreugde en hartseer gegee. Jakob het Ragel liefgehad (29:18) en was bereid om sewe jaar vir haar te werk by haar pa Laban. Ragel was die bron van sy vreugde, sodat die sewe jaar vir hom soos 'n paar dae gevoel het (29:20).

Toe hy na sewe jaar sy vrou opeis, het Laban 'n bruilofsfees gereël. Jakob se huwelik begin op ' $n$ vreugdevolle noot, maar dra die kiem van baie ongelukkigheid. Laban het die oudste suster, Lea, aan hom as vrou gegee onder die voorwendsel dat sy Ragel was. Jakob se eie bedrog teenoor Esau (Gn 27) kom terug op sy eie hoof.

$\mathrm{Na}$ onderhandelings met Laban het Jakob toe getrou met Ragel. Die vorige perikoop sluit af deur te bevestig dat Jakob steeds meer van Ragel gehou het as van Lea. Oënskynlik het Jakob nou wat sy hart begeer, maar dit blyk gou dat die tafel gedek was vir driedubbele hartseer in sy huis. Die inleidende vers van die geboortevertelling (29:31) skets die omstandighede: 
- Lea is ongelukkig, want sy, wat as oudste en eerste vrou van Jakob ten minste gelyk behandel behoort te word, is die nie-geliefde. Sy kry kinders, maar ontbeer wat haar suster het, naamlik die liefde van Jakob.

- Ragel is ongelukkig, want sy bly kinderloos. Die Here gee juis vir Lea kinders omdat Hy opkom vir haar as veronregte. Ragel het Jakob se liefde, maar ontbeer wat haar suster het, naamlik kinders.

- Jakob word deur die ongelukkigheid van (en soos dit later blyk: die struweling tussen) sy vrouens geraak. Die feit dat sy lieflingvrou nie 'n erfgenaam voortbring nie, sou vir hom 'n bitter pil wees om te sluk.

\section{NAME AS BOODSKAPPE}

Dit is onbegryplik dat Jakob nie agtergekom het dat hy verkul is voordat hy met Lea gemeenskap gehad het nie, al was Lea waarskynlik gesluierd. Sewe jaar lank was sy oë op Ragel en hy het haar gestalte en bewegings geken. Sy onoplettendheid berei in die vertelling die weg voor vir die gebrek aan kommunikasie wat die geboortevertelling en die verdere geskiedenis van sy huisgesin kenmerk. In die geboortevertelling is daar min dialoog. Waar daar dialoog is, is dit kort en met bitterheid.

Wanneer ' $n$ kind gebore word, gee òf Lea òf Ragel die naam. Die naam word nie soos gebruiklik deur die vader gegee nie. Die uitsprake by die naamgewing is bedoel om indirek te kommunikeer:

- Lea en Ragel gee algemene uitdrukking aan hulle innerlike gevoelens: hulle hartseer, verlange, vreugde, hoop of ander emosies.

- Hulle stuur ten minste deur sommige van die name boodskappe aan mekaar om hulle saak tuis te bring en selfs om mekaar seer te maak.

- Lea, en waarskynlik ook Ragel, kommunikeer deur die naamgewing met Jakob, tot wie hulle andersins nie werklik deurdring nie.

- Die opmerkings by die naamgewing dien ook in 'n besondere sin as 'n wens of gebed tot die Here, soos verder aangetoon sal word. 


\section{NAME VAN VREUGDE EN VERDRIET}

Elke geboorte word gevolg deur die gee van 'n naam. Die naamgewing gaan gepaard met ' $n$ verklaring deur die moeder van die kind. Hierdie verklaring is sowel 'n plegtige uitspraak (statement) as 'n verduideliking (explanation, midrash) van die naam. Gewoonlik is die etimologie van die betrokke naam nie ter sake nie. Die verklaring berus meesal bloot op klankooreenkoms tussen die naam en een of meer bekende Hebreeuse woorde (Von Rad 1972:237; Brueggemann 1982:254; Sarna 1989:206).

Met die uitsondering van Jakob se eersgeborene, Ruben, volg die

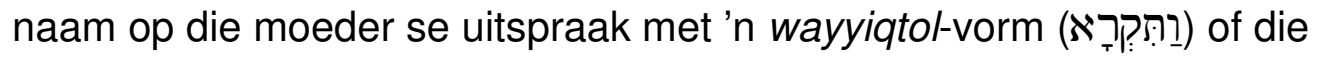

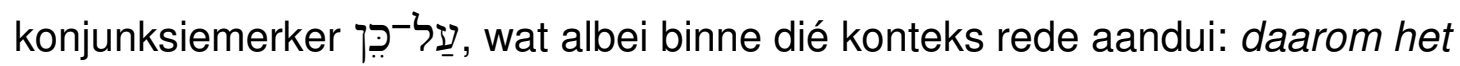
sy hom genoem ....

\subsection{Eerste segment: Lea se kinders}

Die vertelling begin met die geboorte van Lea se eerste vier seuns. Hierdie segment (29:31-35) word as eenheid afgegrens deur te noem dat die Here Lea swanger laat word het (29:31) en dat sy opgebou het om geboorte te skenk (29:35). Die eerste vers (29:31) is 'n inleidende tekseenheid (uitpak/exposition) wat ons inlig oor beide vroue se verleentheid: nie-geliefd wees en kinderloos wees. Beide begeer wat die ander een besit. Die verteller lei die leser om op hierdie stadium simpatie te hê met die nie-geliefde Lea.

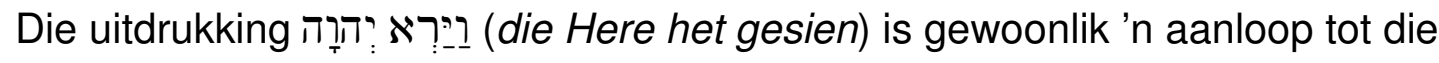
Here se optrede in belang van die swakke en verdrukte (Wenham 1994:243).

- Die naam van die eersgeborene, Ruben (רָארבְן), klink na 'n kombinasie van die werkwoord ראה (sien) in die bevelsvorm en (seun). Kyk, 'n seun! sou 'n gepaste uitroep gewees het by die geboorte van 'n eersteling. Soos met die ander gevalle waar die kinders name ontvang, kom die moeder se plegtige verklaring (of verduideliking) nie direk ooreen met die veronderstelde betekenis van die naam nie. Lea verklaar:

Die Here het my ellende raakgesien. Ja, nou sal my man my liefhê (29:32).

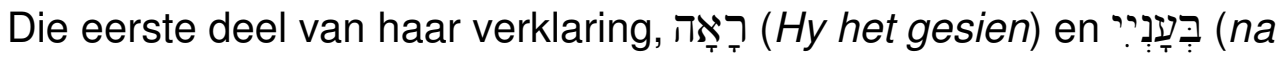

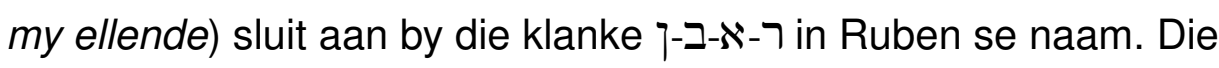
tweede deel van die verklaring, יאמָהבבני (hy sal my liefhê), sinspeel op die klanke א-א-ץ in Ruben se naam. 


\section{Vreugde en verdriet in die huis van Jakob}

Hoewel die naam (wat hier voorop staan) eintlik 'n vreugde-uitroep is, druk Lea se verklaring haar verdriet uit, naamlik haar hunkering na huweliksgeluk. Ruben se geboorte is vir haar 'n manier om Jakob se liefde te verwerf. Ross-Burstall (1994:164-166) wys daarop dat Lea se uitsprake by die geboorte van haar seuns die aard van klaagliedere (laments) het, waar die Here gevra word om op te tree en haar smart te verlig. Westermann $(1981: 575,577)$ beperk haar uitsprake nie tot die klaagliede-genre nie. Volgens hom vertoon Lea se uitsprake 'n himniese karakter omdat dit uiteindelik ook lofprysing bevat.

- Die naam Simeon (שִמְמעוך) herinner aan die Hebreeuse werkwoord שמע (hoor). Van Selms (1967:102) beskou die uitdrukkings van persepsie (sien en hoor) by die eerste twee seuns se geboorte as forensiese terminologie, naamlik dat die Here as regter die hulpgeroep van die veronregte vrou hoor. Die begrippepaar dui in elk geval op kommunikasie met die Here teen die agtergrond van die gebrek aan kommunikasie in Jakob se huis. Lea sê:

Die Here het gehoor dat ek die nie-geliefde is en my hierdie een ook gegee (29:33).

Lea sien in die geboorte van haar tweede seun 'n bewys dat die Here besig is om vir haar saak op te kom. Die Here is die Een wat sien en hoor, al sien en hoor Jakob haar nie. Haar klaagsang bevat hoop op 'n blye uitkoms.

Tog is sy al ver op die pad van moedverloor en lê die verdriet vlak

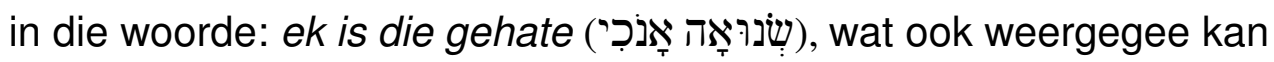
word as: ek is die nie-geliefde. Volgens Wenham (1994:243) sinspeel hierdie woorde van Lea tegelyk op die naam Simeon. So 'n klankooreenkoms is egter nie voor die hand liggend nie.

- Die naam Levi (לִיר) sinspeel ook op 'n bekende Hebreeuse werkwoord: (I) לוה. Hierdie werkwoord beteken in die Qal om te vergesel en in die Nif'al om jouself te bind aan (KBL:475). Lea is oortuig dat haar kinders haar man aan haar geheg sal maak. Daarom sê sy:

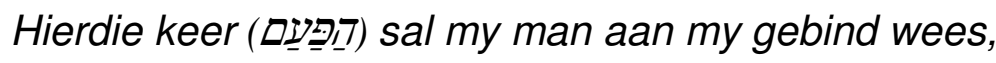
omdat ek vir hom drie seuns in die wêreld gebring het (29:34). 
Dit is opmerklik dat Lea die getal drie noem, waarskynlik met die verwagting dat drie 'n volle getal is. In haar klaaglied beskaam die hoop steeds nie.

Begrippe wat in verband met die eerste drie seuns se name gebruik word, is verwant aan die generiese begrip van vreugde of die gebrek aan vreugde. Lea praat van vreugde, maar openbaar daarin haar diep hartseer. Die name is uitdrukking van haar hartsverlange en is terselfdertyd ' $n$ indirekte kommunikasie, want sy wil Jakob se aandag op haar verlange na hom vestig. Waar sy by die eerste twee seuns nog na die Here verwys het, fokus sy by die derde seun so sterk op Jakob se liefde as die bron van haar vreugde, dat die Here verswyg word.

- Na die "drie", is seun nommer vier 'n verrassing, want Lea se aandag verskuif volledig terug na die Here toe. Sy verwys nie eens na Jakob

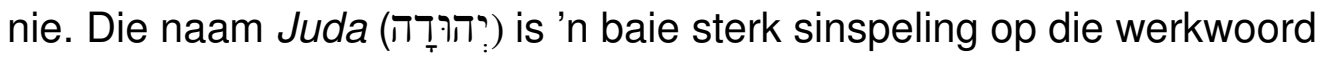
ידה (loof, prys).

Hoewel die betekenis van die naam, soos by die ander seuns, gewoonlik nie ter sake is nie, lei verskeie eksegete die naam Juda wel af van die werkwoord ידה (loof, prys). Die naam kan verstaan word as 'n sametrekking van Ek sal JHWH prys (Waltke 2001:410) of הוּד:ידיָ': (Mag JHWH geprys word) (Millard 1974:217).

Ten opsigte van Juda ervaar sy ongemengde vreugde. In plaas daarvan dat 'n gevoel van eensaamheid haar bestaan vul en sy haar eie waarde ooreenkomstig haar man se afsydigheid meet, transendeer sy haar nood en jubel sy voor God. Dit kom voor of sy gevorder het van die najaag van vervulling tot by daadwerklike vervulling, en van 'n gebrek aan vreugde tot by ware vreugde.

Met haar lofprysing aan die Here, is Lea vir die eerste keer in die vertelling nie besig met Jakob se liefde teenoor haar nie. Sy kommunikeer nou nie met Jakob nie, maar met die Here.

Lea sonder Juda se geboorte uit as sy sê:

Hierdie keer (הֵַָּ) prys ek die Here.

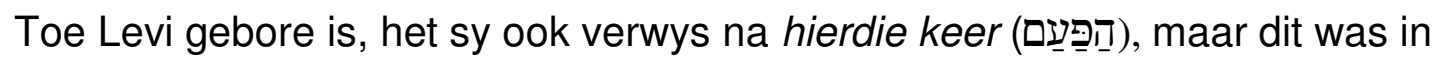
verband met haar verlange na Jakob. Met Levi is 'n drietal afgesluit. Met Juda kom 'n bonus-keer, nóg 'n הַּפ by. Hierdie ekstra keer rig sy haar tot die Here. 


\section{Vreugde en verdriet in die huis van Jakob}

Westermann (1981:577) noem Lea se uitspraak die lofprysing (Lobgelübde) aan die einde van 'n lofpsalm. Ross-Burstall (1994:170) beskou Juda se naamgewing as 'n loflied (vow of praise) wat 'n klaaglied afsluit. In elk geval word die geboorte van Juda deur sy naam en Lea se verklaring retories onderstreep. Sy geboorte beklee 'n besondere plek in die wedywering tussen Lea en Ragel. Dit baan die weg vir die verdere vertelling in Genesis, waar Juda uitgesonder word. Aan Juda is later (49:8-12) die heerskappy toegesê. $\mathrm{Hy}$ is die lofkind (child of praise) wat die disfunksionele gesin weer sou genees (Waltke 2001:410). Van Selms (1967:102) merk op dat dit nie sonder rede is dat hier met die geboorte van Juda 'n pouse intree nie.

\subsection{Tweede segment: Wedywering deur slavinne}

Die tweede segment vorm in die ontwikkeling van die vertelteks die verwikkeling (developing conflict). Elk van die susters bring surrogaatkinders, instaankinders (Ersatzkinder), in die lewe deur middel van hulle slavinne, Bilha en Silpa. Die planne slaag egter nie, maar verdiep alleen die stryd tussen Lea en Ragel.

Sowel Lea as Ragel maak menslike planne. Hulle wedywering met mekaar is suiwer immanent (Meurer 2001:103). In die naamgewing van die kinders is daar geen verwysing na God nie. Wanneer daar in die vertelling rondom die naamgewing na God verwys word, is dit Jakob en Ragel wat met in 'n verwytende trant van God praat: Hý weerhou kinders en daarom moet Hý laat reg geskied. Beide Lea en Ragel sit op moedverloor se vlakte, al probeer hulle hulself deur die instaankinders se name wysmaak dat alles goed gaan.

Kinderloosheid is 'n groot probleem vir enige vrou wat in 'n patriargale samelewing soos dié van die Ou Nabye Ooste leef. Wanneer haar man te sterwe kom, laat dit haar feitlik sonder enige burgerlike regte. Soms is dit ook as straf op sonde gesien (Callaway 1986:16). Onvrugbaarheid kon Ragel die liefde van haar man kos. Haar huidige posisie as bevoorregte vrou in Jakob se huis sou in gedrang kom as sy in gebreke bly om kinders te baar (Taschner 2000:92) en dit sou Lea bevoordeel. Die teks gee egter net die harde beoordeling dat jaloesie die rede vir Ragel se optrede was. Tereg wys Hamilton (1995:266) daarop dat Ragel op Lea afgunstig was en die teks nêrens 'n aanduiding gee dat die teenoorgestelde ook waar is nie, naamlik dat Lea op Ragel afgunstig was.

'n Kort, gespanne dialoog tussen die twee persone wat die naaste aan mekaar staan, Jakob en Ragel, lei die tweede segment van die teks in. Die Hebreeuse dialoog bevat alleen imperatiewe en nominale sinne, wat 'n staccato-effek aan die dialoog gee. Alter (1981:188) maak die volgende opmerking na aanleiding van die Hebreeuse sintaksis van hierdie kort 
gedeelte: The whole dialogue is a matter of a few lines, but it succeeds in amply suggesting the tangle of emotions - love, consideration, jealousy, frustration, resentment, rage - that constitutes the conjugal relationship.

Ragel eis kinders van Isak (30:1) in 'n uitbarsting van frustrasie en woede. Sy skuif die skuld op Jakob af. Jakob is net so geïriteerd as hy met 'n retoriese vraag antwoord: Is ek dan in die plek van God wat jou daarvan weerhou om kinders te hê? (30:2). Ragel vind geen simpatieke oor nie, maar eerder 'n skimp dat sy God se straf ervaar. Jakob se reaksie kan ook gesien word as 'n verklaring dat hy van sy posisie afstand doen (statement of abdication). Terselfdertyd gee sy verklaring die kernboodskap van die teks, naamlik dat alleen God lewe kan gee (Brueggemann 1982:254). Die soek na 'n nageslag buite God se seën om, is tevergeefs.

Sonder omhaal van woorde gee Ragel haar slavin aan Jakob met die woorde: sodat óók ék (גַַ-אָנכיר) uit haar gebou kan word (30:3). Jakob stem in en doen wat sy grootvader Abraham op Sarai se versoek gedoen het. Jakob se reaksie word as stilswyende instemming voorgestel (30:4). Die verteller beklemtoon op hierdie manier die gebrek aan kommunikasie in Jakob se huis.

Ragel se plan is volgens tydgenootlike gebruike. Ragel sê: Bilha moet

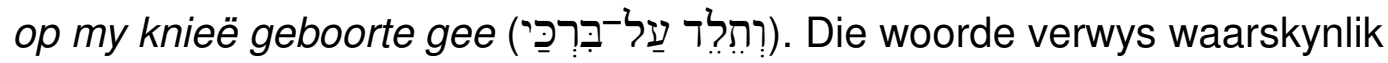
nie, soos meeste eksegete in navolging van De Vaux $(1965: 42,51)$ dit verstaan, na die wyse van geboorte nie (dat die kind in 'n aannemingsrite letterlik op Ragel se knieë gebore sou word). Volgens Richter (1979:436-437)

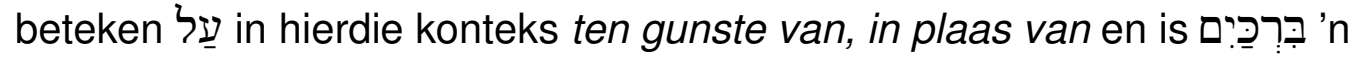
eufemisme vir moederskoot. Dit kan beteken dat die kind simbolies op die moederskoot geplaas is (Sarna 1989:207-208) of bloot as aangenome kind van Ragel gereken sou word. Hierdie uitdrukking wat Ragel gebruik, leen hom

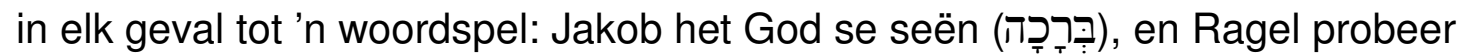

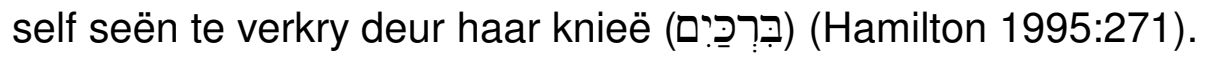

Seebass (1999:339-340) wys daarop dat kinders van 'n slavin eintlik as kinders van die man gereken word. Die eienares se regte oor die slavin verminder wanneer die man by haar kinders verwek. Dit is daarom opmerklik dat Ragel die naam van die kind gee. Deur die kind so volledig as haar eie te ag, oorspeel Ragel haar rol.

- Op dié manier is Dan (דיך) gebore. Die woord verskaf, "vindicate", uitspraak lewer ten gunste van iemand) vind weerklank in hierdie naam, en volgens Wenham (1994:245) vind ook die woord נתן (gee) daarin weerklank. Dit kom in die twee dele van Ragel se uitspraak na vore: 


\section{Vreugde en verdriet in die huis van Jakob}

God het aan my reg verskaf deur my te verhoor en aan my 'n seun te gee.

Deur die naamgewing wil sy aan die wêreld vertel dat sy van 'n lewensreg beroof is (waarskynlik deur God), omdat Lea kinders het en sy nie. Sy gee te kenne dat God nou die onreg reggestel het. Haar uitspraak impliseer dat sy tog, ten spyte van die maatreëls wat sy getref het, haar tot God gewend het en gebid het om 'n kind.

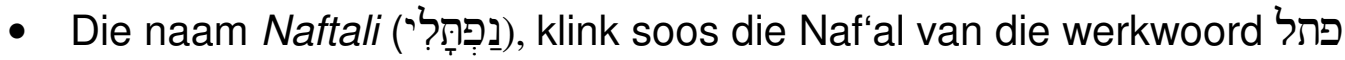
(draai, stoei, vleg of slinks) (KBL:788; Jacob 1934:596; Hamilton

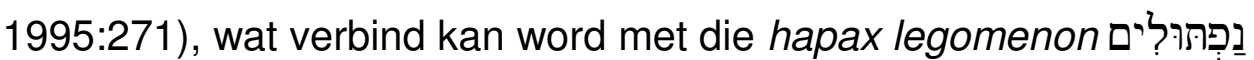
(stryd) in Ragel se uitspraak:

Ek was in 'n Goddelike stryd met my suster gewikkel (30:8a).

Ragel dui haar stryd aan as 'n Goddelike (אֶלדים) stryd. Sy sien haar stryd met Lea eintlik as 'n worsteling met God, wat haar moederskoot toesluit (vgl 30:2). Ragel se stryd met God herinner aan wat Jakob sê oor sy worsteling by die Jabbok (Genesis 32:30).

As vrou is Lea deur kindergeboorte in haar reg bevestig. Nou sê Ragel:

[Ó]ók (모) ek is in my reg bevestig (30:8b).

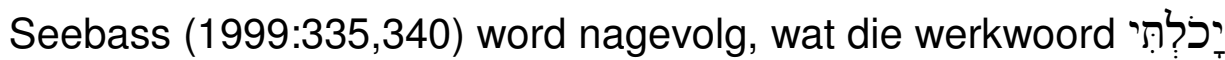
verstaan as reg verskaf (schaffen, bestättigen). Kinders is vir haar 'n middel om 'n vermeende onreg wat God haar aangedoen het, reg te stel. Taschner (2000:95-96) bring die betekenis van die werkwoord in verband met die erfreg. Ragel het deel aan Jakob se erfenis bekom deur haar instaankinders.

\footnotetext{
${ }^{3}$ Vgl Westermann (1981:579) vir 'n opsomming van verklarings van hierdie moeilike uitdrukking. Die verklaring van Fokkelmann (1975:135), Sarna (1989:208), Seebass (1999:338) en andere word nagevolg, naamlik dat haar stryd met haar suster ook 'n stryd vir/met God (Gotteskampf) is, 'n geloofsworsteling om sy seën, omdat Hy haar nie kinders gee nie. Die genitief word as objektiewe genitief verstaan. Jacob (1934:600) verstaan dit as subjektiewe genitief ('n geveg waarby God betrokke is, ' $n$ geveg om God se saak). Ander verklaarders (byvoorbeeld Holwerda 1954:112; Westermann 1981:579) beskou אֶלה אלדים hier as 'n intensiewe vorm (bitter swaar stryd). ' $n$ Variasie op hierdie siening is dat אלה die aard van die stryd beskryf, naamlik een is wat menslike mag te bowe gaan (Speiser 1964:231).
} 
Met die herhaalde gebruik van a dui die teks daarop dat Ragel haarself in wedywering met haar suster beskou en deur naywer en vyandskap teenoor haar suster gedryf word. Ragel redeneer in terme van regte wat sy meen haar toekom en die geboorte van die twee instaankinders is vir haar soos die oorwinning in 'n regsgeding. Die ironie is egter dat Ragel aan haar self reg verskaf in die gewaande onreg, want die geboorte van haar seuns was die vrug van haar eie plan. Ragel opereer nie soos Lea op die vlak van vreugde en verdriet nie, maar op die vlak van regte en vergelding.

Lea doen haar suster na. Toe sy besef dat sy nie meer kinders in die wêreld bring nie, het sy ook háár slavin, Silpa, aan Jakob gegee. Dis opmerklik dat die teks nie noem dat Silpa ook op Lea se knieë geboorte moes gee of dat Jakob met Silpa gemeenskap gehad het nie. Volgens Meurer (2001:99) is hierdie "reduksie in vertelstyl" 'n aanduiding van 'n fokusverskuiwing. Lea eien die instaankinders nie so direk toe as Ragel nie (Seebass 1999:229). Hierdie reduksie kan egter óók (of bloot) 'n versnelling in die verteltempo aandui, wat in verteltekste kenmerkend van 'n oploop-episode (pre-peak) is wat die knooppunt (climax) dikwels voorafgaan (Longacre 1996:38). Dit dui dan daarop dat die leser direk nadat van Lea se instaankinders vertel is (30:9-15), die klimaks of knoop van die vertelling kan verwag, wat inderdaad gebeur in 30:14-16.

Lea bring die name van die twee seuns van Silpa direk in verband met geluk:

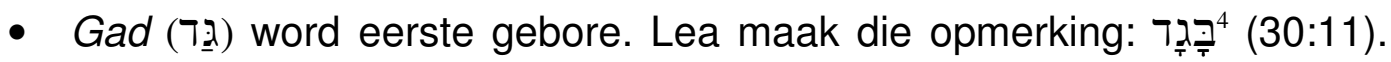
Dit is 'n kriptiese opmerking wat vertaal kan word met:

Ek het geluk (fortune, luck) gevind.

Lea opereer steeds binne die begripsveld van vreugde, hoewel die inhoud van die begrip geluk hier neig na 'n uiterlike geluk en selfs gelukstoeval (Van Selms 1967:104).

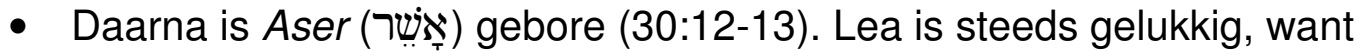
hierdie naam herinner'n mens aan die werkwoordstam (II) אשר, wat in die Pi'el beteken: om gelukkig te verklaar (KBL:95). As die vrou deur die jongmeisies gelukkig geprys word in Hooglied 6:9, word dié

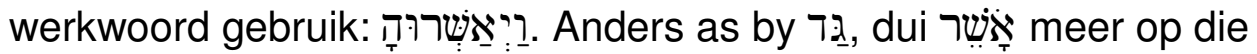

\footnotetext{
${ }^{4}$ Qere (גָרָ - geluk het gekom); waarskynlik is die Ketiv beter:
} 


\section{Vreugde en verdriet in die huis van Jakob}

inwendige toestand van geluk (Van Selms 1967:104). In die singewing van die name is daar van Gad na Aser 'n verinniging van geluk. Psalm 1 begin met die woorde אַשְׁרי (gelukkig is die man). Lea is oortuig dat die vroue van haar sal sê, na die geboorte van Aser: אָשְׁרי (gelukkig is dié vrou) (vgl 30:13b). Sy het immers gedoen wat van vroue verwag word in 'n samelewing waar sukses van vroue volgens die aantal kinders gemeet word: sy en haar slavin het vir haar man ses seuns in die wêreld gebring (Laffey 1990:36).

Lea word in die tweede segment steeds in 'n positiewe lig gestel. Wenham (1994:246) dink aan bedekte leedvermaak wanneer Lea ook haar slavin aan Jakob gee. Hoewel sy nie openlik met haar suster kompeteer nie, is dit moontlik dat sy tog wou wys: alles wat Ragel kan doen, kan sy nadoen en selfs verbeter. Lea was nie in dieselfde eksistensiële krisis as Ragel nie en het nie nodig gehad om instaankinders te laat verwek nie. 'n Noukeuriger lees van die teks wys egter dat sy Jakob se aanvaarding en liefde soek. Sy soek vreugde van 'n persoonlike verhouding en nie die lekkerkry om iemand na die kroon te steek nie. In die naamgewing sinspeel sy op geluk en blydskap en nie op vergelding soos Ragel nie.

Die surrogaatkinders bied in beide gevalle nie die ontknoping wat hulle name suggereer nie. Lea se geluk is bloot surrogaatgeluk, soos Ragel se vergelding net surrogaatvergelding is:

- Die geluk waarvan die name van Gad en Aser getuig, verskil van die louter vreugde met die naamgewing van Juda. Dit gaan oor vreugde wat Lea ervaar en wat op haarself keer, eerder as vreugde in lofprysing. Gad en Aser se naamgewing verwys glad nie na die Here nie en selfs nie na Jakob nie. Dit gaan oor geluk per se. Die goeie geluk wat die twee seuns bring, kan nie vergoed vir die hartseer afgetrokkenheid van Jakob nie.

- Ragel se twee instaankinders word deur Lea se twee instaankinders beantwoord. Haar agterstand bly dieselfde. Juis die geboortes deur middel van die slavinne beklemtoon haar onvrugbaarheid: almal (nou al drie vroue) behalwe Ragel kan kinders in die wêreld bring.

In segment 2 verdiep beide susters se hartseer dus. Hierdie opgeslotenheid van beide susters in hulle eie doolhof van verdriet, sonder sig op God wat gee, berei die weg voor vir die volgende segment. 


\subsection{Derde segment: Wedywering deur liefdesappels en gebed}

Die derde segment word deur 'n vinjet ingelui, naamlik die liefdesappelsinsident. Die lelikste in beide susters kom na vore. Ooreenkomstig die tipiese patroon van klimaktiese verteltekste verteenwoordig hierdie insident ook die maak-of-breek klimaks - die knooppunt - van die verhaal. Hier word die klimaks (wat in 'n sin die dieptepunt van die vertelling is) deur dialoog, wat net die nodigste sê, aangedui.

Ragel maak aanspraak op die liefdesappels (דרוּדָאים) wat Lea se seun, Ruben, in die veld gekry het. Lea is verontwaardig en verwyt haar dat sy haar man gevat het. As eerste vrou het sy immers eerste reg op die liefde van Jakob. Ragel stel voor dat sy die aand by Jakob kan slaap in ruil vir die liefdesappels. Dat Lea dadelik ingestem het, word deur die teks geïmpliseer, want sy konfronteer Jakob met die feit dat sy betáál het (met klem word die status absolutus hier gebruik) om 'n nag by hom te wees. Uit hierdie insident blyk 'n paar belangrike sake:

- Ragel sien in die gebruik van die liefdesappels 'n oplossing vir haar probleem. Dis nie duidelik van watter tipe plant die liefdesappels afkomstig is nie, maar verskeie moontlikhede word in die literatuur genoem (vgl Jacob 1934:588 en Seebass 1999:341 vir 'n opsomming). Daar is 'n duidelike klankooreenkoms tussen דרוּדָאים (liefdesvrugte / love fruits) en die woord vir geliefde (דiר) (Jacob 1934:598; Waltke 2001:412). Uit die klankooreenkoms en die konteks kan met redelike sekerheid afgelei word dat die רדּרְָּאים as 'n geslagsprikkelende en vrugbaarheidsmiddel beskou is en dat dit skaars en dus gesog was.

- Ragel is in haar plannetjiesmakery 'n geesgenoot van Jakob, wat sy broer uit sy eersgeboortereg verkul het (25:31-34; 27:18-27). Haar eerste plan, naamlik om deur haar slavin kinders vir Jakob te kry, was uit die staanspoor gedoem tot mislukking. Hierdie tweede plan van haar, naamlik om voortplanting met "medisyne" uit die veld te manipuleer, sluit aan by wat Jakob met sy vee probeer doen in die perikoop wat volg (30:25 e v). Ragel se plan is egter ' $n$ waagstuk. Lea kan op die wyse bevrug word en haar voorsprong bo Ragel behou of vergroot.

- Ragel het 'n posisie van mag. As Jakob se geliefde vrou kon sy effektief die (by)vrouens se toegang tot Jakob versper. Ragel se voorstel word verskillend beoordeel. Fokkelmann (1975:140) sien in Ragel se voorstel getuienis dat sy as persoon gegroei het. Sy is nou 


\section{Vreugde en verdriet in die huis van Jakob}

bereid om, al is dit tydelik, skiet te gee. Seebass (1999:341) wys daarop dat Jakob ten minste oorwegend saam met Ragel was en het hy dus nie meer met Lea geslaap het nie. Dit kan afgelei word uit die mededeling dat Lea nie meer kinders gehad het nie (29:35), maar dat sy direk na hierdie insident weer swanger geword het (30:17).

- Lea sien in die transaksie 'n oplossing vir háár probleem. Sy wil in die eerste plek by Jakob wees. Die begin van 30:17 impliseer dat sy tot God gebid het vir nog 'n kind. Tog is nog 'n kind vir haar slegs ' $n$ middel tot die doel, naamlik om Jakob aan haar te bind. Lea maak van Ragel se plan gebruik om basiese huweliksregte terug te wen. Die opmerking dat sy daarna vir Jakob (לְיְיעבה) 'n seun in die wêreld bring, is in ooreenstemming met die ander geboorteberigte. Die uitdrukking beteken nie, soos Jacob (1934:599-600) aflei, dat sy deur die transaksie haarself as grootmoedige plaasvervanger vir haar kinderlose suster beskikbaar stel en dat die twee seuns wat nou gebore word, as kinders van Ragel geld nie. Jacob se siening is uit die konteks "volkome onhoudbaar" (Holwerda 1954:113).

- Lea moet self vir Jakob vertel van die reëling wat sy en Ragel getref het. Dis vir al die betrokke partye vernederend:

- Lea moet haar voor Jakob gaan verneder deur die terme van die ooreenkoms uit te spel. Gispen (1983:88) sien egter in Lea se optrede opportunisme, naamlik dat sy vir Jakob inwag voordat hy by Ragel kan uitkom. Van Selms (1967:105) noem Lea se aankondiging aan Jakob 'n triomfantelijke scherts. Die naamgewing van die laaste kinders van Lea verraai egter nie sodanige houding by Lea soos Gispen en van Selms nie dit verstaan nie.

- Verder moet Jakob hoor dat hy as persoon verhandel is. Hy aanvaar dit blykbaar sonder teëspraak - in skrille kontras met sy reaksie in 30:1-3 (Seebass 1999:341; Meurer 2001:100). Dit is die dieptepunt van sy bannelingstyd: hy is nie net in diens van Laban nie (die woordstam עבד kenmerk sy bannelingstyd), maar kom as 't ware in sy vrouens se diens te staan; hy verkoop nie alleen sy arbeid aan Laban nie, maar word self verhandel (Fokkelmann 1975:130,138). Insgelyks word Jakob se bannelingstyd gekenmerk deur die woord שכר (huur): sy verhouding met Laban is gereduseer tot ' $n$ huurling-verhouding en 
hier word sy verhouding met sy eerste vrou ook tot dié vlak verlaag (Wenham 1994:247). Jakob word die speelbal van sy vroue.

- Lea se aankondiging van die transaksie is ook vir Ragel 'n vernedering, want daardeur herinner Lea juis vir Jakob aan sy geliefde vrou se onvrugbaarheid.

Die verteller lig die leser in dat God na Lea geluister het (30:17). Die

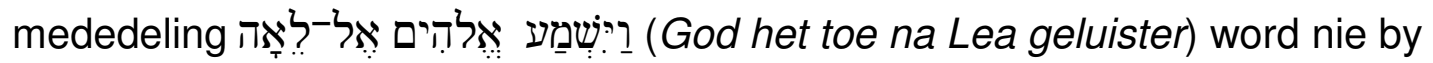
die geboorte van die ander kinders in hierdie segment herhaal nie en het waarskynlik betrekking op die hele segment. Dat Lea by herhaling moeder van kinders word, is bewys van gebedsverhoring. Daar is in 'n geringer of groter mate 'n herstel in die verhouding met Jakob en ook dit kan as verhoring van gebed gesien word. Die herstel van die verhouding blyk uit die driedubbele swangerskap en die name wat aan die kinders gegee word, wat nie so sterk van 'n verlange na Jakob spreek as die eerste vier nie.

Die implikasie van die gebedsverhoring is dat God kan doen wat liefdesappels nie kan doen nie; Lea het immers haar liefdesappels aan Ragel verkoop en Ragel het eers later swanger geword. Slegs as die teks gerekonstrueer word, kan afgelei word dat die verteller die liefdesappels aan Ragel se swangerskap verbind (so Westermann 1981:581). Die teks in sy eindgestalte dui juis op die teenoorgestelde.

God kan ook doen wat die ruiltransaksie met Ragel nie kan doen nie, naamlik om Lea te beloon met die toegeneëndheid van haar man. Die teks beklemtoon met groter nadruk dat God die oorsaak van die geboortes is, as wat die voorafgaande vertelling dit doen (Jacob 1934:597).

Hierdie is die eerste uitdruklike verwysing na gebed. 'n Mens kan aflei dat die naamgewing van Lea se ander kinders deel was van voortgaande gebede. 'n Positiewe naam is dikwels gebuik as 'n wens of selfvervullende profesie of herinnering aan God (of 'n afgod) van jou diepste begeertes. RossBurstall (1994:167) beskou die naamgewing van al Lea se kinders as gebede. Of dit ook die geval was met die kinders van haar slavin en of sy eerder op daardie stadium in haar eie verdriet vasgeval was (sien 5.2 hier bo), word nie vir ons gesê nie.

Die geboorte van twee seuns en 'n dogter rond die geboortegeskiedenis van Lea se kinders af. Die verwysings na hulle geboortes is kort en op die punt af, wat daarop dui dat die spanningslyn ná die klimaks (die liefdesappels-insident) steeds voortgedra word. Die probleem van Ragel se kinderloosheid is nog nie opgelos nie, maar verdiep eerder namate Lea haar laaste kinders kry. In die vertelling word die laaste twee seuns met nadruk genommer: vyf (30:17) en: ses (30:20). 


\section{Vreugde en verdriet in die huis van Jakob}

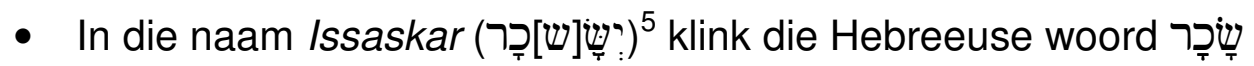
(betaling, huur, loon). Die leser se eerste reaksie sou wees om hierdie naam te verbind aan die direk voorafgaande liefdesappels-insident,

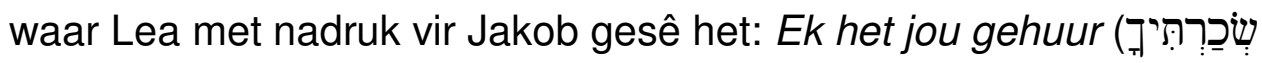
(שָׁ). Fokkelmann (1975:138) wys daarop dat die naam Issaskar om hierdie rede vir Jakob in 'n slegte lig stel. Lea gryp in haar verduideliking egter verder terug, naamlik toe sy haar slavin, Silpa, aan haar man gegee het (30:18). Sy dui die geboorte van Issaskar aan as beloning dáárvoor:

God het my loon gegee, omdat ek my slavin aan my man gegee het.

Jacob (1934:597) is van oordeel dat Lea 'n opoffering gemaak het deur haar slavin met Jakob te deel (daarom die loon), terwyl Ragel haar slavin aan Jakob gegee het om kinders te bekom. Dis egter waarskynliker dat Lea die voor die hand liggende sinspeling op Jakob wat gehuur is, verberg met haar sinspeling op haar vorige (instaan)kind se geboorte. Daaruit blyk lojaliteit teenoor Jakob.

Die naamgewing van Issaskar gee nie getuienis van die hunkering na Jakob, wat die geboorte van die eerste vier kinders gekenmerk het nie. Die loon wat sy ontvang het, verwys moontlik nie bloot na Issaskar nie, maar na 'n nuwe toegeneëndheid van Jakob. Uit haar woorde blyk hoop en selfs vreugde. Hierdie geboorte is 'n wendingspunt in die vertelling, waar God begin om haar vernedering om te keer.

- Lea sinspeel in twee opsigte op die naam Sebulon (זְרֵלוּן), haar se sesde seun. Eers sê sy:

God het my hierdie keer 'n mooi geskenk gegee.

סie werkwoord זבד (skenk) en die naamwoord זְֶרד ('n geskenk) sinspeel op die stamkonsonante ז-ב- in die naam Sebulon.

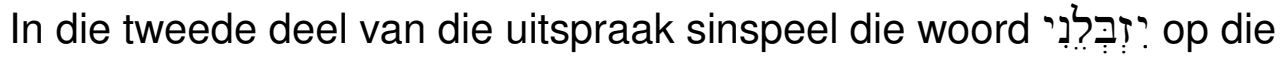
naam Sebulon. Dis ' $n$ woord met duideliker sinspeling as in die eerste deel,

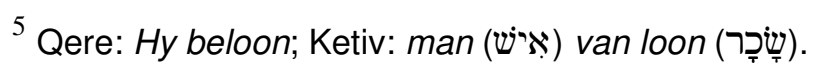


maar onduideliker betekenis: Die vertaling van Seebass (1999:336, 342) van die werkwoordstam זבל word nagevolg, naamlik die hof maak (umwerben): ${ }^{6}$

Hierdie keer sal my man my die hof maak, want ek het vir hom ses seuns in die wêreld gebring.

Die woord (hierdie keer) word weer gebruik soos by die geboorte van Juda, die laaste seun van haar eerste groep seuns. Hierdie keer, na ses seuns, is Lea seker dat haar man haar aanvaar en eer. Haar se opmerking by die naamgewing getuig van optimisme en kom die naaste aan haar lofprys by die geboorte van Juda. Haar vyfde seun was vir haar 'n beloning; hierdie laaste seun sien sy as ' $n$ meevaller, as bonus.

Die oppervlakkige blydskap waarvan die twee instaankinders se name getuig, is nou dieper veranker in Jakob se toegeneëndheid. Die teks sê nie of Lea se persepsie oor Jakob realisties is nie, maar daar is, soos by die geboorte van die vyfde seun, nie meer die stryd om Jakob se aandag te kry nie. Haar verwysingspunt is egter nog steeds Jakob, soos by die eerste drie seuns se geboorte. Haar vreugde word in terme van haar man bepaal. Die lofprysing by die geboorte van Juda bly uitsonderlik in die ry van geboortes in die huis van Jakob.

- Lea se tweede geboortesiklus word afgesluit deur die geboorte van 'n dogter, Dina. Sy word slegs in die verbygaan genoem, met geen singewing aan haar naam nie. Sy funksioneer wel in 'n latere teks (34:1-31), daarom word sy genoem. Dina is egter nie een van die stamvaders nie. Trouens, 32:23 noem slegs elf kinders van Jakob.

Die huweliksvervulling wat Lea begin ervaar, vorm die ontknoping van die vertelling sover dit Lea betref. Ragel se kinderloosheid is nog onopgelos. Lea se verdere kinders en 'n klaarblyklike toenadering van Jakob tot Lea, vererger eerder haar probleem.

Met hierdie groot probleem van Ragel sluit die derde segment en ook die teks af. Ooreenkomstig die tipiese patroon van 'n klimaktiese vertelteks is 30:22-24 ' $n$ verdere ontknoping van die verhaal. Dit is nie die klimaks van die vertelling nie (so: Waltke 2001:414) en Seebass 1999:337, 342).

\footnotetext{
${ }^{6}$ Die hapax legomenon זבל word uiteenlopend verklaar en vertaal. Gispen (1983:89) motiveer die vertaling wat meeste ouer Bybelvertalings volg, naamlik: bly by. Gamberoni (1977:534) se vertaling, ophemel, op die hande dra (verhimmeln, auf Händen tragen) word nagevolg deur onder andere die NIV (treat ... with honour) en die NBV (op handen dragen). KBL se verklaring: verdra (nie wegstuur nie), word deur Westermann (1981:581) nagevolg. Von Rad (1972:236) vertaal: tot regmatige vrou maak (zur rechtmaßige Frau machen).
} 


\section{Vreugde en verdriet in die huis van Jakob}

Ragel het tot dusver nog geen troos in haar hartseer ervaar nie, terwyl Lea wel haar kinders as vertroosting het en blykbaar geslaag het om Jakob nader aan haar te trek. God laat nou ook aan Ragel reg geskied. Hy het Ragel onthou (בְ? (30:22) (30:2).

- Dieselfde uitdrukking (רַּ - Hy het onthou) word gebruik wanneer die Here uiteindelik aan Hanna 'n kind gee (1 Sam1:19). Soos Ragel was Hanna ook lank kinderloos terwyl haar meedingster, Penina, seuns en dogters gehad het. Die uitdrukking is tipiese verbondstaal, waar God na 'n tyd op die nood van sy kinders let. Die uitdrukking dra volgens Childs (1962:41) spore van 'n himne. רַּ in is 'n sterker uitdrukking as met Lea, van wie bloot gesê word dat die Here na haar geluister het

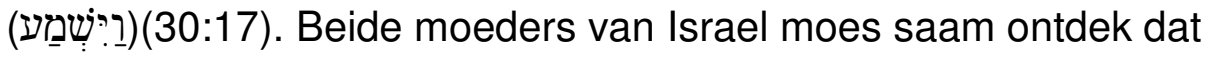
onvrugbaarheid nie 'n probleem is met menslike oplossings nie. Nuwe

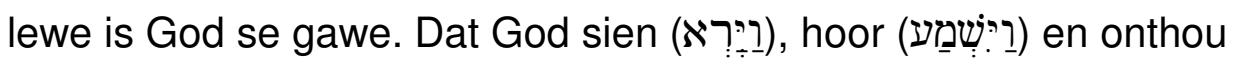
(1) in: is die hart van die evangelie.

- Ragel gee geboorte aan Josef (יוסךך) (30:22-24). Haar planne - ook die liefdesappels - het nie gehelp nie, maar slegs God se ontferming, naamlik dat Hy haar onthou het en na haar gebede geluister het. Soos Jakob waarskynlik sy eerste vrou, Lea, weer raakgesien het, het God vir Ragel onthou nadat dit lank gelyk het of Hy haar vergeet het.

Ragel maak twee uitsprake, wat beide op die klank af sinspeel op die naam Josef. Hierdie twee uitsprake, wat op twee Hebreeuse werkwoorde gegrond is, geskied op dieselfde patroon as wat Lea gedoen het met die geboorte van Sebulon (30:19-20) en dui nie noodwendig op tekskorrupsie of dat twee bronne gebruik is nie. Ragel se eerste uitspraak is:

\section{God het my skande weggeneem.}

Hierdie uitspraak sluit aan by die Hebreeuse werkwoord אסף (bymekaarmaak, wegneem). Kinderloosheid was vir haar 'n skande. Die feit dat die skande weggeneem is, is vir haar 'n rede vir blydskap. Nou het sy sowel die liefde van haar man as 'n seun. Hierin vind die vertelling sy tweede ontknoping.

Ragel se tweede uitspraak (30:24b) is teleurstellend:

Mag die Here my nog 'n seun gee. 
Die naam Josef word hier verbind aan die Hebreeuse werkwoord ף (byvoeg, voortgaan). Die imperfektum word gewoonlik as 'n wens of bede verstaan, maar kan ook 'n stelling wees: Die Here sal my nog 'n seun gee. Die ontknoping van haar verhaal en daarom ook haar vreugde, is nie volkome nie. Volgens haar is sy nog nie heeltemal in die gelyk gestel nie. Haar eie verhaal word oopgelaat vir verdere verwikkelings.

\section{SLOTSOM}

God word aan die begin en einde van die geboortevertelling (29:31-35; 30:1724) uitdruklik aangedui as dié Een wat kinders gee. Hy is die Hoofkarakter in die vertelling en nie soseer die twee aartsmoeders met hulle innerlike en onderlinge konflik nie. Die omraming van die teks met die Naam Jahwe, wat kenmerkend is van die aartsvadervertelling, is 'n aanduiding dat die geboortevertelling ingebed is in die ontvouende plan van die aartsvadervertelling.

Die tweede verklaring van Ragel, wat ook die sloteenheid (closure) van die geboortevertelling is, laat doelbewus die vertelling oop vir die verdere verloop van die aartsvadervertelling. Nie alleen berei dit die weg vir die geboorte van Benjamin (35:16-19) nie, maar Ragel vind bevestiging van haar voorkeurposisie in Jakob se huis, wat brandstof vir verdere konflik verskaf tot in die Josefsvertelling (Taschner 2000:94). Die wanverhouding tussen Josef (kind van Ragel) en die ander kinders (meeste van Lea) is 'n voortsetting van die stryd tussen Lea en Ragel.

Aan die ander kant is daar in die geboortevertelling ' $n$ fyn balans. Aanvanklik lê die simpatie by Lea, maar uiteindelik moet die leser ook vir Ragel jammer kry toe Lea byna in die oortreffende trap in die gelyk gestel word. Lea kry uiteindelik haar deel, maar ook Ragel. God is teenoor beide vroue barmhartig, maar ook regverdig. Hierdie fyn balans word in die verdere aartsvadervertelling voortgedra. Die verband met die aartsvadergeskiedenis is egter 'n onderwerp op sy eie en is buite die fokus van hierdie artikel.

Lea worstel in die vertelling met hartseer en vreugde. Uiteindelik groei sy in haar hantering van hartseer en vreugde. Ten spyte van 'n sprankie hoop aan die einde van die vertelling dat sy as mens gegroei het, bly Ragel in haar eie klein doolhof van verdriet vasgedraai omdat sy redeneer op die vlak van vergeldig. 


\section{Vreugde en verdriet in die huis van Jakob}

\section{Literatuurverwysings}

Alter, R 1981. The art of Biblical narrative. New York: Basic Books.

Bellis, A O 1999. A sister is a forever friend: Reflections on the story of Rachel and Leah. JRT 55-56(2), 109-115.

Brueggemann, W 1982. Genesis. Atlanta, GA: John Knox. (Interpretation.)

Callaway, M 1986. Sing, o barren one: $A$ study in comparative midrash. Atlanta, GA: Scholars. (SBLDS 91.)

Childs, B S 1962. Memory and tradition in Israel. London: SCM. (SBT 37.)

De Stadler, L G 1994. Groot tesourus vir Afrikaans. Halfweghuis: Southern Boekuitgewers.

De Vaux, R 1961. Ancient Israel: Its life and institutions. London: Darton, Longman \& Todd.

Dillard, R B \& Longman, T 1994. An introduction to the Old Testament. Grand Rapids, MI: Zondervan.

Fokkelmann, J P 1975. Narrative art in Genesis: Specimens of stylistic and structural analysis. Assen: Van Gorkum. (Studia Semitica Neerlandica 17.)

Gamberoni, J 1977. s v Zebul (זְרל). ThWAT.

Gispen, W H 1983. Genesis: Vertaald en verklaard. Kampen: Kok. (COT.)

Hamilton, V P 1995. The book of Genesis, Chapters 18-50. Grand Rapids, MI: Eerdmans.

Holwerda, B 1954. Dictaten I: Historia Revelationis Veteris Testamenti. Kampen: s.i.

Koehler, L \& Baumgartner, W (Hrsg) 1988. A bilingual dictionary of the Hebrew and Aramaic Old Testament: English and German. 3. Auflage. Leiden: Brill. (Aangedui as $\mathrm{KBL}^{3}$.)

Kratz, R G 2000. Die Komposition der erzählenden Bücher des Alten Testaments: Grundwissen der Bibelkritik. Göttingen: Vandenhoeck \& Ruprecht. (UTB für Wissenschaften 2157.)

Krueger, P P 2000. Die beskrywing van gedagtesamehang: 'n Eksegetiese hulpmiddel, geïllustreer aan die hand van Genesis 2. ThD-proefskrif, Potchefstroomse Universiteit vir $\mathrm{C} \mathrm{H} \mathrm{O}$.

Laffey, A L 1990. Wives, harlots and concubines: The Old Testament in feminist perspective. London: SPCK Holy Trinity Church.

Lehming, S 1963. Zur Erzählung von der Geburt der Jakobsöhne. VT 13, 74-81.

Longacre, R E \& Levinsohn, S 1978. Field analysis of discourse, in Dressler W U (ed), Current trends in linguistics, 103-122. New York: De Gruyter. (RTT/UzT 2.)

Longacre, R E1996. The grammar of discourse, $2^{\text {nd }}$ ed. New York: Plenum. (Topics in language and linguistics.)

Louw, J P \& Nida, E A (eds) 1989. Greek-English lexicon of the New Testament based on semantic domains, volume $1,2^{\text {nd }}$ ed. New York: United Bible Societies.

Meurer, T 2001. Der Gebärwettstreit zwischen Leah und Rahel: der Erzählaufbau von Gen 29, 31-30, 24 als Testfall der erzählerischen Geschlossenheid einer zusammenhanglos wirkenden Einheit. BN 107-108, 93-108.

Millard, A R 1974. The meaning of the name Judah. ZAW 86, 216-218.

Rad, G von 1972. Das erste Buch Mose, Genesis: Übersetzt und erklärt. Göttingen: Vandenhoeck \& Ruprecht. (ATD 2/4.) 
Richter, H-F 1979. "Auf den Knien eines anderen gebären”: Zur Deutung von Gen 30, 3 und 50, 23. ZAW 91, 436-437.

Ross-Burstall, J 1994. Leah and Rachel: A tale of two sisters. WW 14(2), 162-170.

Sarna, N M 1989. Genesis: The traditional Hebrew text with the new JPS translation. Philadephia, PA: The Jewish Publication Society. (JPS Torah Commentary.)

Seebass, H 1999. Genesis II/2, Vätergeschichte II (23, 1-36, 43). Neukirchen-Vluyn: Neukirchener Verlag.

Speiser, E A 1964. Genesis. New York: Doubleday. (Anchor Bible.)

Swanson, J A 2001. A Dictionary of Biblical Languages with Sementic domains: Hebrew Old Testament. Logos Research Systems.

Taschner, J 2000. Verheissung und Erfülling in der Jakoberzählung (Gen 25, 19-33, 17): Eine Analyse ihrer Spannungsbogens. Freiburg im Breisgau: Herder. (Herders Biblische Studien 27.)

Van Selms, A 1967. Genesis, deel II. Nijkerk: Callenbach. (POT.)

Wahl, H M 1997. Die Jakobserzählungen: Studien zu ihrer mündlichen Überlieferung, Verschriften und Historizität. Berlin: De Gruyter. (BZAW 258.)

Waltke, B K 2001. Genesis: A commentary. Grand Rapids, MI: Zondervan.

Wenham, G 1994. Genesis 16-50. Dallas, TX: Word Books. (WBC 2.)

Westermann, C 1981. Genesis. 2. Teilband 12-36. Neukirchen-Vluyn: Neukirchener Verlag. (BKAT I/2.) 